\title{
Replacing alfalfa hay with dry corn gluten feed and Chinese wild rye grass: Effects on rumen fermentation, rumen microbial protein synthesis, and lactation performance in lactating dairy cows
}

\author{
X. Y. Hao, H. Gao, X. Y. Wang, G. N. Zhang, and Y. G. Zhang ${ }^{1}$ \\ College of Animal Science and Technology, Northeast Agricultural University, Harbin, 150030, China
}

\begin{abstract}
This experiment was conducted to investigate nutrient digestibility, rumen microbial protein synthesis, and lactation performance when a portion of alfalfa was replaced with combinations of dry corn gluten feed (DCGF) and Chinese wild rye grass in the diet of lactating cows. Six multiparous and 3 primiparous Chinese Holsteins were arranged in a replicated $3 \times 3$ Latin square experiment for 21 -d periods. The animals were fed 1 of 3 treatment diets during each period: (1) 0\% DCGF (0DCGF); (2) 6.5\% DCGF (7DCGF); and (3) 11\% DCGF (11DCGF). Diets were isonitrogenous, and a portion of alfalfa hay was replaced with DCGF and Chinese wild rye grass, with similar concentrate mixtures and corn silage contents. The dry matter intake was greater for 11DCGF $(21.9 \mathrm{~kg} / \mathrm{d})$ than for 0DCGF $(20.7 \mathrm{~kg} / \mathrm{d})$ or 7DCGF $(21.2 \mathrm{~kg} / \mathrm{d})$. The treatment diets did not result in difference in milk production, fat and lactose concentration, or yield. Compared with 0DCGF, the ration containing 11\% DCGF improved the milk protein concentration. Dry matter and neutral detergent fiber digestibility was greater for 7DCGF (62.7\% and $45.6 \%$ ) and 11DCGF (63.1\% and $47.2 \%$ ) than for ODCGF (59.4\% and $42.3 \%$ ), and the nitrogen digestibility was similar for the 3 treatments. The concentration of rumen volatile fatty acids was higher in cows fed the 11DCGF diet than in those fed the 0DCGF diet, with no difference between the 7DCGF and 11DCGF diets. The estimated microbial crude protein yield was greater for the 11DCGF diet $(1985.1 \mathrm{~g} / \mathrm{d})$ than for the 0DCGF diet $(1745.0 \mathrm{~g} / \mathrm{d})$, with no difference between the 0DCGF and 7DCGF diets. Thus, it appears that feeding DCGF and Chinese wild rye grass in combination can effectively replace a portion of alfalfa hay in the rations of lactating dairy cows.
\end{abstract}

Received June 21, 2016.

Accepted December 30, 2016.

${ }^{1}$ Corresponding author: zhangyonggen@sina.com
Key words: dry corn gluten feed, lactating performance, nutrient digestibility, purine derivative

\section{INTRODUCTION}

Alfalfa is an excellent forage used for dairy cattle (Viands et al., 1988), but the availability of this feed ingredient in the global herbivorous animal industry is limited. The quantity of alfalfa cannot meet the needs of dairy industry, and the gap between high-quality forage supply and demand is increasing rapidly, especially in China (Zhu et al., 2013). Therefore, the imported volume of alfalfa hay increases year by year, which increases feeding costs and decreases the economic benefits of the dairy industry. In contrast, large amounts of fibrous co-product are produced each year, with low lignin content and a large proportion of potentially digestible fiber, which may be used as fiber feed for dairy cows to replace a portion of alfalfa hay.

Corn gluten feed (CGF) is a co-product of the wet milling process and includes bran and steep (Bothast and Schlicher, 2005). It has approximately $1.91 \mathrm{Mcal}$ $\mathrm{NE} / \mathrm{kg} \mathrm{DM}$, which is similar to corn, and 45 to $\sim 50 \%$ NDF, which is similar to many forages (NRC, 2001). Additionally, it contains highly digestible corn fiber and is high in CP (Kelzer et al., 2008). These qualities are desirable in feedstuffs for lactating cows. The bran is then mixed with steep liquor and stored as wet corn gluten feed (WCGF) or with water removed as dry corn gluten feed (DCGF). However, the WCGF is corruptible and should be stored in a sealed structure to reduce spoilage. Thus, the texture of the WCGF restricts flow and makes handling difficult. However, DCGF is available as flakes or pellets, it is easier to store and transport, and the feed is more available to a greater number of dairy farms than WCGF. Available research data in terms of using DCGF as a nonforage source to substitute for high-quality forages in dairy cow diets are less common. Firkins et al. (1991) reported that a $20 \%$ DCGF and $1 \%$ sodium bicarbonate combination was a commendable replacement for corn silage for dairy cows. VanBaale et al. (2001) reported 
that replacing a portion of alfalfa hay, corn silage, and corn grain with WCGF resulted in higher DMI and production efficiency. Farran et al. (2006) determined that WCGF could be used as an energy source to reduce the need for alfalfa hay. Cattle on diet that received WCGF with the removal of alfalfa hay from their diet had an increase in DMI, as well as improved carcass characteristics. Biricik et al. (2007) suggested that when 18 and $25 \%$ of the corn silage was replaced by DCGF, rumination time, chewing activities, and ruminal $\mathrm{pH}$ were negatively affected. The optimum level for the addition of DCGF was found to be below $18 \%$ of the diet for a healthy rumen and chewing behavior in dairy cows. In addition, replacing feedstuffs low in CP, such as corn grain or silage, with DCGF, which is high in $\mathrm{CP}$, may result in higher concentrations of $\mathrm{CP}$ in rations, potentially increasing $\mathrm{N}$ excretion (Broderick, 2003; Groff and $\mathrm{Wu}, 2005)$. The digestible fiber from DCGF may supply the ruminal microbes with readily fermentable energy and promote microbial CP (MCP) synthesis (Calsamiglia et al., 2008). The AA profile of MCP is a close match to the animal's requirements and is believed to be highly digestible (Clark et al., 1992; NRC, 2001). Nonforage sources of fiber do not stimulate rumination activity as effectively as dietary forage because of their small particle size (Mertens, 1997). Allen and Grant (2000) reported that the physically effective NDF of CGF was $11 \%$ of NDF on the basis of rumination time and ruminal $\mathrm{pH}$. Therefore, it is important to consider the combination of DCGF and long fiber feeds when it is used in the ration of lactating cows. Chinese wild rye grass is a type of gramineous forage grass in northeast China, and it is commonly used in dairy farms.

The objective of this research was to determine the effects on the digestibility of feed, MCP synthesis, and lactating performance when a portion of alfalfa hay was replaced with DCGF and Chinese wild rye grass in the diets of lactating Holstein cows.

\section{MATERIALS AND METHODS}

\section{Animals, Diets, and Experimental Design}

The use and care of the animals in this study were approved by the Animal Care Advisory Committee, Northeast Agricultural University (Harbin, China), and all the experimental procedures in this study were in accordance with the university's guidelines for animal research. The experimental animals were provided by the Comprehensive Breeding Farm (Harbin, China). Six multiparous and 3 primiparous Holsteins $(\mathrm{BW}=$ $596 \pm 46.0$ and $\mathrm{DIM}=91 \pm 22.8$; mean $\pm \mathrm{SD}$ ) were used in a replicated $3 \times 3$ Latin square experiment with 21-d periods (14 d of diet adaption and $7 \mathrm{~d}$ of sample collection). Groups were balanced for parity and production and consumed 1 of 3 treatment diets during each period. The treatment diets contained similar concentrate mixtures and corn silage, but different proportions of roughage and DCGF. The treatments were (1) 0\% DCGF (0DCGF); (2) 6.5\% DCGF (7DCGF); and (3) 11\% DCGF (11DCGF). The ration ingredient composition is shown in Table 1. Three isonitrogenous diets were formulated to meet the animals' requirements for energy, protein, minerals, and vitamins based on Cornell-Penn-Miner (Boston et al., 2000). Given the high level of NDF and CP contained in DCGF, it was combined Chinese wild rye grass and replaced portions of alfalfa hay. Chinese wild rye grass in rations ensured the requirement of effective fiber. Cows were housed in individual stall barns and fed twice daily (0600 and $1630 \mathrm{~h})$ at $105 \%$ ad libitum intake, and milked twice

Table 1. Ingredients and chemical composition ${ }^{1}(\%$ of DM) of experimental diets

\begin{tabular}{|c|c|c|c|}
\hline \multirow[b]{2}{*}{ Item } & \multicolumn{3}{|c|}{ Treatment $^{2}$} \\
\hline & 0DCGF & 7DCGF & 11DCGF \\
\hline \multicolumn{4}{|l|}{ Ingredient } \\
\hline Alfalfa hay & 23.4 & 13.4 & 5.94 \\
\hline Dry corn gluten feed & 0 & 6.5 & 11.0 \\
\hline Chinese wild rye grass & 0 & 3.5 & 6.46 \\
\hline Corn silage & 23.3 & 23.3 & 23.3 \\
\hline Ground corn & 22.32 & 22.32 & 22.32 \\
\hline Soybean meal & 11.5 & 11.5 & 11.5 \\
\hline Cottonseed meal & 7.73 & 7.73 & 7.73 \\
\hline $\mathrm{DDGS}^{3}$ & 4.6 & 4.6 & 4.6 \\
\hline Beet pulp & 4.22 & 4.22 & 4.22 \\
\hline Sodium bicarbonate & 0.5 & 0.5 & 0.5 \\
\hline Ca salts of long-chain fatty acids & 1.4 & 1.4 & 1.4 \\
\hline Limestone & 0.38 & 0.38 & 0.38 \\
\hline Salt & 0.12 & 0.12 & 0.12 \\
\hline Premix $^{4}$ & 0.53 & 0.53 & 0.53 \\
\hline \multicolumn{4}{|l|}{ Chemical composition } \\
\hline $\mathrm{CP}$ & 18.0 & 17.8 & 17.7 \\
\hline $\mathrm{NDF}$ & 32.5 & 33.7 & 34.4 \\
\hline $\mathrm{ADF}$ & 20.3 & 19.3 & 18.5 \\
\hline $\mathrm{NFC}^{5}$ & 36.5 & 37.1 & 35.3 \\
\hline Starch & 21.2 & 21.4 & 21.5 \\
\hline $\mathrm{NE}_{\mathrm{L}},{ }^{6} \mathrm{Mcal} / \mathrm{kg}$ of DM & 1.68 & 1.70 & 1.68 \\
\hline
\end{tabular}

${ }^{1}$ Compositions of experimental diets were calculated according to the chemical analysis and inclusion rate of ingredients.

${ }^{2}$ ODCGF $=0 \%$ of DM dry corn gluten feed; 7DCGF $=6.5 \%$ of DM dry corn gluten feed; 11DCGF $=11 \%$ of DM dry corn gluten feed.

${ }^{3}$ DDGS $=$ distillers dried grains with solubles.

${ }^{4}$ Premix contained (DM basis) $99.07 \%$ of ash, $14.27 \%$ of $\mathrm{Ca}, 5.42 \%$ of $\mathrm{P}, 4.96 \%$ of $\mathrm{Mg}, 0.05 \%$ of $\mathrm{K}, 10.67 \%$ of $\mathrm{Na}, 2.98 \%$ of $\mathrm{Cl}, 0.37 \%$ of $\mathrm{S}$, $11 \mathrm{mg} / \mathrm{kg}$ of Co, $577 \mathrm{mg} / \mathrm{kg}$ of Cu, $4,858 \mathrm{mg} / \mathrm{kg}$ of Fe, $51 \mathrm{mg} / \mathrm{kg}$ of I, $1,806 \mathrm{mg} / \mathrm{kg}$ of Mn, $13 \mathrm{mg} / \mathrm{kg}$ of Se, $1,694 \mathrm{mg} / \mathrm{kg}$ of Zn, $115,240 \mathrm{IU} / \mathrm{kg}$ of vitamin A, 46,100 IU $/ \mathrm{kg}$ of vitamin D, and $576 \mathrm{IU} / \mathrm{kg}$ of vitamin $\mathrm{E}$. ${ }^{5} \mathrm{NFC}=100-\% \mathrm{NDF}-\% \mathrm{CP}-\%$ ether extract $-\%$ ash.

${ }^{6}$ Calculated based on MOA (2004). 
HAO ET AL.

Table 2. Nutrient composition (\% of DM unless otherwise noted; mean \pm SD) of forages and dry corn gluten feed used in the experimental diets $(n=8)$

\begin{tabular}{|c|c|c|c|}
\hline Composition & Alfalfa hay & Chinese wild rye grass & Dry corn gluten feed \\
\hline DM, \% & $92.0 \pm 0.81$ & $90.7 \pm 0.63$ & $89.7 \pm 0.63$ \\
\hline OM, $\%$ & $89.2 \pm 0.50$ & $92.3 \pm 0.48$ & $92.1 \pm 0.45$ \\
\hline $\mathrm{CP}$ & $18.5 \pm 1.60$ & $6.8 \pm 0.86$ & $22.0 \pm 1.26$ \\
\hline NDF & $39.7 \pm 1.35$ & $62.3 \pm 1.96$ & $50.3 \pm 2.07$ \\
\hline $\mathrm{ADF}$ & $30.4 \pm 0.86$ & $33.7 \pm 1.52$ & $14.1 \pm 1.12$ \\
\hline $\mathrm{NFC}^{1}$ & $32.6 \pm 1.09$ & $24.5 \pm 0.96$ & $21.2 \pm 0.85$ \\
\hline Lignin & $7.9 \pm 0.75$ & $12.0 \pm 0.87$ & $2.4 \pm 0.63$ \\
\hline Starch & $1.6 \pm 0.23$ & $0.4 \pm 0.05$ & $6.5 \pm 1.29$ \\
\hline $\begin{array}{l}\mathrm{NE}_{\mathrm{L}},{ }^{2} \mathrm{Mcal} / \mathrm{kg} \text { of } \\
\mathrm{DM}\end{array}$ & $1.3 \pm 0.10$ & $0.86 \pm 0.14$ & $1.5 \pm 0.10$ \\
\hline
\end{tabular}

daily at 0630 and $1830 \mathrm{~h}$. The cows had free access to drinking water.

\section{Sample Collection, Measurements, and Analyses}

The feed offered was recorded every day and was adjusted to allow for $5 \%$ orts, and for d 15 to 17 of each period, the feed offered and refused was weighed for 3 consecutive days to determine the DMI. Ration, orts, and feedstuffs samples were collected on d 15 and 16 of each period. The particle size of TMR was measured by using the Penn State Particle Separator as described by Heinrichs and Kononoff (2002). Samples of feeds and orts were dried for $48 \mathrm{~h}$ at $60^{\circ} \mathrm{C}$ in a forced-air oven and ground to pass through a 1-mm screen in a Wiley mill (Arthur H. Thomas Co., Philadelphia, PA) before analysis. The contents of DM, OM, CP, ADF, lignin, and starch were determined according to the procedures of the AOAC International (2000). The NDF content was analyzed using the Ankom A200 fiber analyzer (Ankom Technology, Macedon, NY) by the method of Van Soest et al. (1991). The chemical composition of the individual forages and DCGF are listed in Table 2, and the diet compositions are presented in Table 3.

The milk production was recorded and milk samples were collected during 6 consecutive milkings on d 15,
16, and 17 of each period. Each day, two 50-mL aliquots of milk were mixed (5:5), and one sample was preserved using Bronopol (milk preservative; D\&F Control Systems, San Ramon, CA). The daily milk yield was averaged for d 15 to 17 of each period. Milk subsamples were analyzed in DHI center (Harbin, China) for fat, true protein, lactose, and TS using a 4-channel spectrophotometer (MilkoScan, Foss Electric, Hillerød, Denmark). Milk SCC was measured using a cell counter (DeLaval, Tumba, Sweden). Another sample with no preservative was stored at $-20^{\circ} \mathrm{C}$ for analysis of MUN, according to the diacetyl monoxime-binding method described by Zhu et al. (2013).

Blood samples were collected from the mammary vein of each cow into heparinized test tubes at approximately $3 \mathrm{~h}$ after the morning feeding on $\mathrm{d} 18$ of each period. The samples were then centrifuged at 3,000 $\times g$ for 15 min to obtain plasma. The plasma samples were frozen at $-20^{\circ} \mathrm{C}$ and later thawed for analysis of the BUN (Wang et al., 2007).

On d 19, 20, and 21 of each period, rumen fluid samples (approximately $200 \mathrm{~mL}$ ) were collected using an oral stomach tube approximately $3 \mathrm{~h}$ after the morning feeding (Wang et al., 2014). The $\mathrm{pH}$ was immediately measured using a pH meter (PB-10; Sartorius Co., Göttingen, Germany). The samples were centrifuged

Table 3. Particle size distribution of experimental diets ${ }^{1}$

\begin{tabular}{|c|c|c|c|c|c|}
\hline \multirow[b]{2}{*}{ Particle size, $\mathrm{mm}$} & \multicolumn{3}{|c|}{ Treatment $^{2}$} & \multirow[b]{2}{*}{ SEM } & \multirow[b]{2}{*}{$P$-value } \\
\hline & 0DCGF & 7DCGF & 11DCGF & & \\
\hline$>19.0$ & $8.9^{\mathrm{a}}$ & $8.0^{\mathrm{ab}}$ & $6.8^{\mathrm{b}}$ & 0.42 & 0.04 \\
\hline $8.0-19.0$ & $36.0^{\mathrm{a}}$ & $33.7^{\mathrm{b}}$ & $29.5^{\mathrm{c}}$ & 0.63 & 0.001 \\
\hline $1.18-8.0$ & $37.7^{\mathrm{b}}$ & $39.5^{\mathrm{b}}$ & $43.1^{\mathrm{a}}$ & 0.56 & 0.002 \\
\hline$<1.18$ & $17.4^{\mathrm{b}}$ & $18.8^{\mathrm{b}}$ & $21.6^{\mathrm{a}}$ & 0.41 & 0.001 \\
\hline
\end{tabular}

${ }^{\mathrm{a}-\mathrm{c}}$ Means within a row with different superscripts differ $(P<0.05)$.

${ }^{1}$ Proportion of TMR (as fed) retained on each screen of the Penn State Particle Separator. ${ }^{2} 0 \mathrm{DCGF}=0 \% \mathrm{DM}$ dry corn gluten feed; $7 \mathrm{DCGF}=6.5 \% \mathrm{DM}$ dry corn gluten feed; $11 \mathrm{DCGF}=11 \%$ DM dry corn gluten feed. 
at $3,000 \times g$ for $15 \mathrm{~min}$, and the supernatant was separated and stored at $-20^{\circ} \mathrm{C}$ for future analysis of ammonia-N and VFA.

Spot fecal samples were collected for all cows at 0600 and $1800 \mathrm{~h}$ on d 19, 20, and 21 of each period. Approximately $500 \mathrm{~g}$ of feces were collected from the rectum and composited for individual cows in consecutive 3 sample days in each period. Fecal samples were dried at $65^{\circ} \mathrm{C}$ in a forced-air oven, ground to pass through a 1-mm screen in a Wiley mill (Arthur H. Thomas Co.), and stored in sealed plastic containers at $4^{\circ} \mathrm{C}$ until analyses. The ground samples were analyzed for DM, N, ash, NDF, and ADF using the same procedures as described for feed. Apparent total-tract nutrient digestibility was calculated using indigestible NDF (12-d ruminal incubation in 25- $\mu$ m-pore-size bags) as an internal marker as described by Lee and Hristov (2013), based on the concentration of indigestible NDF in the diet and feces.

\section{In Situ Degradation}

In situ rumen degradation of DM and CP of the 3 experimental diets was determined using the method described by Nuez-Ortín and Yu (2010) with 3 ruminally cannulated Holstein cows. The basal diet (\% of DM) consisted of $50.3 \%$ concentrate mixture, $21.5 \%$ corn silage, $18.0 \%$ alfalfa hay, and $10.2 \%$ Chinese wild rye hay and was fed 2 times daily for a total DMI of $1.5 \%$ of BW. The TMR samples used for rumen degradation analysis were dried at $60^{\circ} \mathrm{C}$ in a forced-air oven and ground to pass through a $3-\mathrm{mm}$ screen in a Wiley mill (Arthur H. Thomas Co.) before analysis. Seven grams of samples was weighed and placed into numbered nylon bags $(10 \times 20 \mathrm{~cm}, 50-\mu \mathrm{m}$ pore size; Ankom Technology). All of the nylon bags were tied to the end of a 40-cm polyester mesh bag, which was used to hold the bags in the rumen. The bag was placed in the ventral sac of the rumen through the ruminal cannula to incubate for $2,4,8,12,16,24,36$, and $48 \mathrm{~h}$. After incubation, all bags were removed from the rumen and rinsed under cold tap water until the water was clear. The bags were then dried at $60^{\circ} \mathrm{C}$ for $48 \mathrm{~h}$ and weighed. The residues and original diet samples were ground for DM and CP analysis. The nonlinear model described by Ørskov et al. (1980): $p=a+b[1-\exp (-c t)]$ was used to estimate the constants of the in situ degradation, where $p=$ the rate of disappearance at time $t(\mathrm{~h})$, $a=$ the rapidly degradable fraction (the soluble fraction), $b=$ the slowly degradable fraction, and degraded at rate $c(c>0)$. The effective degradability $(d g)$ was calculated according to the equation: $d g=a+b c /(c$ $+k p)$, where $a, b$, and $c$ are the constants described above. The passage rate outflow from the rumen $(k p)$ was assumed to be $4.6 \% / \mathrm{h}$ (Krizsan et al., 2010).

\section{Estimation of MCP Yield and MP}

Urinary purine derivatives (PD) were used to estimate the MCP yield in the rumen (Chen and Gomes, 1992). Urine samples of all the cows were collected during urination with stimulation at 0600 and $1800 \mathrm{~h}$ on d 19, 20, and 21 of each period and then pooled by volume for each cow, and $10 \mathrm{~mL}$ of each subsample was acidified with $40 \mathrm{~mL}$ of $\mathrm{H}_{2} \mathrm{SO}_{4}(0.036 \mathrm{~mol} / \mathrm{L})$ and frozen $\left(-20^{\circ} \mathrm{C}\right)$. The urine samples were analyzed for urea $\mathrm{N}$ using the colorimetric method (Rahmatullah and Boyde, 1980). The PD (allantoin and uric acid) content was analyzed according to the method described by Chen and Gomes (1992), and creatinine was analyzed using a colorimetric picric acid assay according to the procedures of Shingfield and Offer (1999). Creatinine has been validated as a marker to estimate urine volume (Leonardi et al., 2003). In calculating urine volume, creatinine output was assumed to average $28 \mathrm{mg} / \mathrm{kg}$ of BW as estimated by Valadares et al. (1999). Cows were weighed on a weighing scale on d 18 of each period.

The MP was estimated as the sum of the intestinally absorbable MCP (IAMCP) and intestinally absorbable dietary protein (IADP). The IAMCP was calculated by the following equation: IAMCP $=\mathrm{MCP} \times$ 0.64 (NRC, 2001), and the IADP was estimated by the equation: $\mathrm{IADP}=\mathrm{RUP} \times \mathrm{CP}$ intake $\times \mathrm{IDP}$, where IDP refers to the intestinal digestibility of RUP, determined from the residue of feedstuff incubated in the rumen for $16 \mathrm{~h}$, according to a modified 3-step procedure (Gargallo et al., 2006).

\section{Statistical Analysis}

Data on feed intake, milk production performance, feed efficiency, rumen fermentation, urine creatinine, urine $\mathrm{PD}, \mathrm{MCP}, \mathrm{N}$ conversion, and urea $\mathrm{N}$ concentration were analyzed by PROC MIXED using SAS (version 9.1, SAS Institute Inc., Cary, NC). The following model was used for the analysis as a replicated $3 \times 3$ Latin square design:

$$
Y_{i j k m}=\mu+\mathrm{S}_{i}+\mathrm{C}(\mathrm{S})_{i j}+\mathrm{P}_{k}+\mathrm{T}_{m}+\mathrm{E}_{i j k m},
$$

where $Y_{i j k m}$ is the dependent variable; $\mu$ is the overall mean, $\mathrm{S}_{i}$ is the fixed effect of square $i$; $\mathrm{C}(\mathrm{S})_{i j}$ is the random effect of cow $j$ within square $i$; $\mathrm{P}_{k}$ is the fixed effect of period $k ; \mathrm{T}_{m}$ is the fixed effect of treatment $m$; $\mathrm{E}_{i j k m}$ is the residual error. In situ DM and CP degradation constants ( $a, b, c$, and $d g$ ), RUP, and intestinal digestion variables were determined using the MIXED model, where the individual cow was considered a random effect and the treatment was used as a fixed effect. Statistical significance was defined as $P \leq 0.05$, with 
highly significant values defined as $P<0.01$. Trends were defined as $0.05<P \leq 0.10$.

\section{RESULTS}

\section{Milk Production and Components}

The results of feed intake and milk yield are listed in Table 4. Compared with the cows consuming 0DCGF and 7DCGF, those consuming the 11DCGF diet had a greater $(P<0.01)$ DMI. No differences were found among the treatment diets in milk yield, fat, and lactose concentration or yield. Cows fed the 11DCGF diet tended $(P=0.07)$ to have a higher ECM yield. The milk protein content was higher $(P=0.04)$ for the cows fed 11DCGF compared with those fed ODCGF, with no difference between the 7DCGF and 0DCGF or the 11DCGF values. The milk total solids content and yield were similar among the diets, and the effect of treatment on feed efficiency was not significant $(P=0.74)$.

\section{In Situ Rumen Digestion}

The results for the in situ degradation of the DM and CP are presented in Table 5. For the DM degradation, 11DCGF had a higher $a(P<0.01)$ and $c(P<$ $0.05)$ values but a lower $b$ value $(P<0.05)$ than the 0DCGF diet. The $d g$ was higher for the 11DCGF diet than 0DCGF $(P=0.01)$, and no difference was found between 7DCGF and 0DCGF or 11DCGF. The $b$ values for CP degradation were similar among the treatments, whereas 11DCGF exhibited a higher $a$ value than 0DCGF $(P<0.01)$ and 7DCGF $(P<0.05)$. The $d g$ value of $\mathrm{CP}$ for 11DCGF was higher $(P<0.01)$ than that of 0DCGF, with no difference between 7DCGF and 0DCGF. The RUP for 11DCGF was lower $(P<$ 0.01 ) than that for 0DCGF, with no difference between 7DCGF and 0DCGF.

\section{Rumen Fermentation}

The rumen fermentation characteristics are listed in Table 6. Rumen $\mathrm{pH}$ did not differ among the 3 diets $(P=0.72)$. The ammonia-N concentrate was lower for the 7DCGF diet than for the 0DCGF and 11DCGF diets $(P<0.01)$, with no difference between 0DCGF and 11DCGF. The total ruminal VFA concentration was lower $(P<0.01)$ in 0DCGF than in the 7DCGF and 11DCGF diets, with no difference between the 11DCGF and 7DCGF diets. The cows fed the 7DCGF and 11DCGF diets had higher ruminal acetate $(P=$ $0.02)$, propionate $(P<0.01)$, and butyrate $(P=0.04)$ concentrations than the cows fed the 0DCGF diet. However, the molar proportions of these VFA in total VFA were similar among the diets. No difference existed in the ratio of acetate to propionate among the 3 diets.

Table 4. Lactation performance in dairy cows fed 3 experimental diets based on alfalfa, dry corn gluten feed, and Chinese wild rye grass

\begin{tabular}{|c|c|c|c|c|c|}
\hline \multirow[b]{2}{*}{ Item } & \multicolumn{3}{|c|}{ Treatment $^{1}$} & \multirow[b]{2}{*}{ SEM } & \multirow[b]{2}{*}{$P$-value } \\
\hline & 0DCGF & 7DCGF & 11DCGF & & \\
\hline DMI, kg/d & $20.7^{\mathrm{b}}$ & $21.2^{\mathrm{b}}$ & $21.9^{\mathrm{a}}$ & 0.28 & 0.001 \\
\hline \multicolumn{6}{|l|}{ Yield, $\mathrm{kg} / \mathrm{d}$} \\
\hline Milk & 32.8 & 33.8 & 34.2 & 0.59 & 0.08 \\
\hline $\mathrm{ECM}^{2}$ & 35.9 & 36.6 & 37.3 & 0.72 & 0.18 \\
\hline Fat & 1.29 & 1.31 & 1.36 & 0.040 & 0.25 \\
\hline Protein & $0.98^{\mathrm{b}}$ & $1.05^{\mathrm{a}}$ & $1.06^{\mathrm{a}}$ & 0.022 & 0.04 \\
\hline Lactose & 1.64 & 1.68 & 1.72 & 0.041 & 0.76 \\
\hline Total solids & 3.73 & 3.93 & 3.87 & 0.092 & 0.30 \\
\hline \multicolumn{6}{|l|}{ Milk composition, \% } \\
\hline Fat & 3.93 & 3.86 & 3.98 & 0.099 & 0.13 \\
\hline Protein & $2.99^{\mathrm{b}}$ & $3.07^{\mathrm{ab}}$ & $3.12^{\mathrm{a}}$ & 0.052 & 0.10 \\
\hline Lactose & 4.99 & 4.95 & 5.01 & 0.049 & 0.45 \\
\hline Total solids & 11.4 & 11.6 & 11.3 & 0.19 & 0.39 \\
\hline Milk efficiency $^{3}$ & 1.57 & 1.60 & 1.59 & 0.03 & 0.74 \\
\hline $\mathrm{SCC}, \times 10^{3}$ cells $/ \mathrm{mL}$ & 327 & 362 & 301 & 41.0 & 0.21 \\
\hline
\end{tabular}

${ }_{\mathrm{a}, \mathrm{b}}$ Means within a row with different superscripts differ $(P<0.05)$.

${ }^{1}$ DDCGF $=0 \%$ of DM dry corn gluten feed; 7DCGF $=6.5 \%$ of DM dry corn gluten feed; $11 \mathrm{DCGF}=11 \%$ of DM dry corn gluten feed.

${ }^{2} \mathrm{ECM}(\mathrm{kg})=0.3246 \times$ milk yield $(\mathrm{kg})+13.86 \times$ fat yield $(\mathrm{kg})+7.04 \times$ protein yield $(\mathrm{kg})($ Orth, 1992).

${ }^{3}$ Milk efficiency $=$ milk yield/DMI. 
Table 5. Constants of DM and CP degradation based on $p=a+b[1-\exp (-c t)],{ }^{1}$ and their effective degradability $(d g)$; and RUP of the 3 experimental diets based on alfalfa, dry corn gluten feed, and Chinese wild rye grass

\begin{tabular}{|c|c|c|c|c|c|}
\hline \multirow[b]{2}{*}{ Item } & \multicolumn{3}{|c|}{ Treatment $^{2}$} & \multirow[b]{2}{*}{ SEM } & \multirow[b]{2}{*}{$P$-value } \\
\hline & 0DCGF & 7DCGF & 11DCGF & & \\
\hline \multicolumn{6}{|l|}{ DM degradation } \\
\hline$a, \%$ & $23.3^{\mathrm{b}}$ & $24.9^{\mathrm{b}}$ & $27.5^{\mathrm{a}}$ & 0.76 & 0.02 \\
\hline$b, \%$ & $54.2^{\mathrm{a}}$ & $53.1^{\mathrm{ab}}$ & $51.1^{\mathrm{b}}$ & 0.70 & 0.05 \\
\hline$c, \%$ & $3.21^{\mathrm{b}}$ & $3.28^{\mathrm{b}}$ & $3.65^{\mathrm{a}}$ & 0.103 & 0.05 \\
\hline$d g^{3}$ & $45.6^{\mathrm{b}}$ & $46.9^{\mathrm{ab}}$ & $50.1^{\mathrm{a}}$ & 0.93 & 0.03 \\
\hline \multicolumn{6}{|l|}{$\mathrm{CP}$ degradation } \\
\hline$a, \%$ & $16.4^{\mathrm{c}}$ & $17.3^{\mathrm{b}}$ & $19.6^{\mathrm{a}}$ & 0.62 & 0.03 \\
\hline$b, \%$ & 61.7 & 59.0 & 58.1 & 1.56 & 0.30 \\
\hline$c, \%$ & $4.07^{\mathrm{b}}$ & $4.33^{\mathrm{b}}$ & $4.86^{\mathrm{a}}$ & 0.078 & 0.001 \\
\hline$d g^{3}$ & $45.4^{\mathrm{b}}$ & $45.9^{\mathrm{b}}$ & $49.4^{\mathrm{a}}$ & 0.65 & 0.009 \\
\hline $\mathrm{RUP}^{4} \%$ of $\mathrm{CP}$ & $54.6^{\mathrm{a}}$ & $54.1^{\mathrm{a}}$ & $50.6^{\mathrm{b}}$ & 0.65 & 0.009 \\
\hline
\end{tabular}

${ }^{\mathrm{a}-\mathrm{c}}$ Means within a row with different superscripts differ $(P<0.05)$.

${ }^{1} p=$ the rate of disappearance at time $t(\mathrm{~h}), a=$ the rapidly degradable fraction in the rumen, and $b=$ the fraction slowly degraded at rate $c(c>0)$.

${ }^{2}$ DDCGF $=0 \%$ of DM dry corn gluten feed; 7DCGF $=6.5 \%$ of DM dry corn gluten feed; $11 \mathrm{DCGF}=11 \%$ of DM dry corn gluten feed.

${ }^{3} d g=$ degradability; $d g=a+b c /(c+k p$ ) (Ørskov et al., 1980), assuming a passage rate $(k p)$ of $4.6 \% / \mathrm{h}$ (Krizsan et al., 2010).

${ }^{4} \mathrm{RUP}=100-\mathrm{RDP}$.

\section{Nutrient Intake and Digestibility}

The total amounts of nutrient intake and apparent total-tract nutrient digestibility are listed in Table 7 . The intakes of DM $(P<0.01)$ and $\mathrm{OM}(P<0.01)$ were greater for the cows fed the 11DCGF diet than for those fed the 0DCGF and 7DCGF diets. The NDF intake for the 11DCGF diet was also higher $(P=0.02)$ than for the 0DCGF diet, with no difference between the 7DCGF and 0DCGF or 11DCGF diets. The total apparent digestibilities of $\mathrm{DM}, \mathrm{OM}, \mathrm{NDF}$, and $\mathrm{ADF}$ were all higher for the 11DCGF and 7DCGF diet than for the 0DCGF diet. No significant difference in the CP digestibility $(P=0.24)$ was found among the 3 diets.

\section{Estimated MCP Yield and MP}

The PD and estimated ruminal MCP production values are listed in Table 8 . The daily urinary excretion of creatinine $(P=0.39)$ and allantoin $(P=0.23)$ were not different among the treatment diets, whereas the uric acid $(P<0.01)$ for 7DCGF and 11DCGF was higher than for the 0DCGF diet. The MCP yield was also higher for cows fed 11DCGF compared with those

Table 6. Effects of feeding 3 experimental diets based on alfalfa, dry corn gluten feed, and Chinese wild rye grass on ruminal $\mathrm{pH}$, ammonia-N, and VFA in dairy cows

\begin{tabular}{|c|c|c|c|c|c|}
\hline \multirow[b]{2}{*}{ Item } & \multicolumn{3}{|c|}{ Treatment $^{1}$} & \multirow[b]{2}{*}{ SEM } & \multirow[b]{2}{*}{$P$-value } \\
\hline & 0DCGF & 7DCGF & 11DCGF & & \\
\hline $\mathrm{pH}$ & 6.50 & 6.51 & 6.47 & 0.069 & 0.72 \\
\hline Ammonia-N, mg/dL & $13.1^{\mathrm{a}}$ & $10.3^{\mathrm{b}}$ & $12.5^{\mathrm{a}}$ & 1.03 & 0.009 \\
\hline Total VFA, mmol & $66.5^{\mathrm{b}}$ & $75.8^{\mathrm{a}}$ & $78.4^{\mathrm{a}}$ & 2.96 & 0.007 \\
\hline Acetate, mmol & $44.4^{\mathrm{b}}$ & $50.4^{\mathrm{a}}$ & $51.6^{\mathrm{a}}$ & 2.17 & 0.02 \\
\hline Propionate, $\mathrm{mmol}$ & $13.3^{\mathrm{b}}$ & $15.2^{\mathrm{a}}$ & $16.4^{\mathrm{a}}$ & 0.60 & 0.001 \\
\hline Butyrate, mmol & $8.79^{\mathrm{b}}$ & $10.18^{\mathrm{a}}$ & $10.46^{\mathrm{a}}$ & 0.463 & 0.04 \\
\hline \multicolumn{6}{|c|}{ Molar proportion, $\mathrm{mmol} / 100 \mathrm{mmol}$} \\
\hline Acetate & 66.7 & 66.5 & 66.7 & 0.66 & 0.21 \\
\hline Propionate & 20.1 & 20.1 & 21.0 & 0.57 & 0.22 \\
\hline Butyrate & 13.2 & 13.4 & 13.4 & 0.34 & 0.79 \\
\hline Acetate:propionate & 3.33 & 3.33 & 3.16 & 0.11 & 0.21 \\
\hline
\end{tabular}

$\overline{\mathrm{a}, \mathrm{b}}$ Means within a row with different superscripts differ $(P<0.05)$.

${ }^{1}$ DDCGF $=0 \%$ of DM dry corn gluten feed; 7DCGF $=6.5 \%$ of DM dry corn gluten feed; $11 \mathrm{DCGF}=11 \%$ of DM dry corn gluten feed. 
Table 7. Intakes and total-tract apparent digestibility in dairy cows fed the 3 experimental diets based on alfalfa, dry corn gluten feed, and Chinese wild rye grass

\begin{tabular}{lccccc}
\hline & \multicolumn{3}{c}{ Treatment $^{1}$} \\
\cline { 2 - 3 } Item & 0DCGF & 7DCGF & 11DCGF & SEM & P-value \\
\hline Intake, kg/d & $19.0^{\mathrm{b}}$ & $19.4^{\mathrm{b}}$ & $20.2^{\mathrm{a}}$ & 0.15 & 0.004 \\
OM & 3.72 & 3.78 & 3.90 & 0.101 & 0.38 \\
CP & $6.73^{\mathrm{b}}$ & $7.15^{\mathrm{ab}}$ & $7.52^{\mathrm{a}}$ & 0.170 & 0.04 \\
NDF & 4.21 & 4.08 & 4.05 & 0.079 & 0.35 \\
ADF & & & & \\
Digestibility, & $59.4^{\mathrm{b}}$ & $62.7^{\mathrm{a}}$ & $63.1^{\mathrm{a}}$ & 1.13 & 0.06 \\
DM & $59.3^{\mathrm{b}}$ & $62.3^{\mathrm{a}}$ & $63.2^{\mathrm{a}}$ & 0.98 & 0.02 \\
OM & $64.6^{\mathrm{b}}$ & 63.8 & 66.5 & 1.12 & 0.24 \\
CP & $42.3^{\mathrm{b}}$ & $45.6^{\mathrm{a}}$ & $47.2^{\mathrm{a}}$ & 1.06 & 0.01 \\
NDF & $27.9^{\mathrm{b}}$ & $31.4^{\mathrm{a}}$ & $34.8^{\mathrm{a}}$ & 1.15 & 0.006 \\
ADF & & & & \\
\hline
\end{tabular}

a,b Means within a row with different superscripts differ $(P<0.05)$.

${ }^{1} \mathrm{DDCGF}=0 \%$ of DM dry corn gluten feed; $7 \mathrm{DCGF}=6.5 \%$ of DM dry corn gluten feed; $11 \mathrm{DCGF}=11 \%$ of DM dry corn gluten feed.

fed 0DCGF diet $(P=0.03)$, with no difference between the 0DCGF and 7DCGF values. No differences $(P>$ $0.05)$ were found in the IDP and IADP values among the dietary treatments. No effects of treatment were observed on the urea $\mathrm{N}$ in the blood $(P=0.29)$ and milk $(P=0.59)$. However, feeding 0DCGF resulted in a lower concentration of urea $\mathrm{N}$ in the urine compared with the 11DCGF diet $(P=0.04)$, with no difference between the 0DCGF and 7DCGF diets $(P=0.13)$.

\section{DISCUSSION}

The CP content of DCGF in this experiment $(22.0 \%$ of DM) was similar to that published in NRC (2001) (23.8\% of DM). In contrast, the NDF content of DCGF $(50.3 \%$ of DM) used in this study was higher than the value reported in NRC (2001) (35.5\% of DM). In the present study, Chinese wild rye grass proportions were increased with the increasing DCGF, and the goals

Table 8. Effects of feeding 3 experimental diets based on alfalfa, dry corn gluten feed, and Chinese wild rye grass on ruminal microbial protein $(\mathrm{MCP})$ synthesis, $\mathrm{N}$ conversion, and urea $\mathrm{N}$ concentration in blood, urine, and milk

\begin{tabular}{|c|c|c|c|c|c|}
\hline \multirow[b]{2}{*}{ Item } & \multicolumn{3}{|c|}{ Treatment $^{1}$} & \multirow[b]{2}{*}{ SEM } & \multirow[b]{2}{*}{$P$-value } \\
\hline & 0DCGF & 7DCGF & 11DCGF & & \\
\hline Creatinine, mmol/d & 157.2 & 153.9 & 160.3 & 4.69 & 0.39 \\
\hline \multicolumn{6}{|l|}{ Urinary $\mathrm{PD},{ }^{2} \mathrm{mmol} / \mathrm{d}$} \\
\hline Allantoin & 352.6 & 370.3 & 390.2 & 15.79 & 0.23 \\
\hline Uric acid & $77.7^{\mathrm{b}}$ & $89.1^{\mathrm{a}}$ & $92.8^{\mathrm{a}}$ & 2.82 & $<0.001$ \\
\hline Endogenous PD & 46.3 & 46.5 & 46.1 & 0.79 & 0.44 \\
\hline $\mathrm{MCP}^{3} \mathrm{~g} / \mathrm{d}$ & $1.745 .0^{\mathrm{b}}$ & $1.875 .9^{\mathrm{ab}}$ & $1.985 .1^{\mathrm{a}}$ & 74.96 & 0.08 \\
\hline $\mathrm{IDP}^{4} \%$ of RUP & 49.9 & 49.0 & 51.2 & 1.06 & 0.37 \\
\hline $\mathrm{IADP}^{5} \mathrm{~g} / \mathrm{d}$ & $1,076.9$ & $1,012.3$ & 968.1 & 45.6 & 0.31 \\
\hline $\mathrm{N}$ conversion ${ }^{6}$ & 0.26 & 0.28 & 0.27 & 0.010 & 0.21 \\
\hline \multicolumn{6}{|c|}{ Urea $\mathrm{N}$ concentration, $\mathrm{mg} / \mathrm{dL}$} \\
\hline Blood & 7.02 & 6.83 & 7.17 & 0.202 & 0.29 \\
\hline Urine & $800.7^{\mathrm{b}}$ & $818.6^{\mathrm{ab}}$ & $866.4^{\mathrm{a}}$ & 34.42 & 0.10 \\
\hline Milk & 15.2 & 14.2 & 14.3 & 0.68 & 0.59 \\
\hline
\end{tabular}

${ }^{\mathrm{a}, \mathrm{b}}$ Means within a row with different superscripts differ $(P<0.05)$.

${ }^{1} 0 \mathrm{DCGF}=0 \%$ of DM dry corn gluten feed; $7 \mathrm{DCGF}=6.5 \%$ of DM dry corn gluten feed; $11 \mathrm{DCGF}=11 \%$ of DM dry corn gluten feed.

${ }^{2} \mathrm{PD}=$ purine derivatives.

${ }^{3} \mathrm{MCP}=$ microbial CP synthesis, calculated as described by Chen and Gomes (1992).

${ }^{4} \mathrm{IDP}=$ measured intestinal digestibility of RUP. The feedstuff incubated in the rumen for $16 \mathrm{~h}$ was used to determine the IDP according to a modified 3-step procedure (Gargallo et al., 2006).

${ }^{5} \mathrm{IADP}=$ intestinally absorbable dietary protein $=\mathrm{RUP} \times \mathrm{CP}$ intake $\times$ IDP.

${ }^{6} \mathrm{~N}$ conversion $=$ milk protein yield $/ \mathrm{CP}$ intake. 
were to manipulate the TMR particle size by partially supplying longer particle length hay to ensure the effectiveness of NDF. The particle size recommendations were published by Heinrichs and Kononoff (2002). Using the Penn State Particle Separator, those researchers suggested that rations should contain 2 to $8 \%$ on the top screen $(>19.0 \mathrm{~mm}), 30$ to $50 \%$ on the second screen $(8.0-19.0 \mathrm{~mm}), 30$ to $50 \%$ on the third screen $(1.18-8.0$ $\mathrm{mm})$, and less than $20 \%$ in the bottom pan $(<1.18$ $\mathrm{mm})$. The 11DCGF diet did not meet the minimum recommendation for particles 8.0 to $19.0 \mathrm{~mm}$, and more than $20 \%$ of the TMR was $<1.18 \mathrm{~mm}$ because of the increase of short fiber source (DCGF). Pereira et al. (1999) reported that replacing forages with short fiber and nonforage fiber sources would reduce the ration particle size and effective fiber and increase the risk of acidosis, displaced abomasum, and milk fat depression. Although rations with DCGF appeared to have a slightly finer particle size, no digestive disorders were detected, nor was milk fat yield depressed (Table 4). In this research, long fiber of Chinese wild rye hay ensured the supply of physically effective fiber in diets. The forage NDF content ranged from $19.8 \%$ for 11DCGF to $23.4 \%$ for the 0DCGF diet. According to the NRC (2001), a lactating cow's rations of $33 \%$ NDF or greater should contain at least $15 \%$ forage NDF. Therefore, the effective fiber was adequate for all treatment diets in this experiment.

In previous research, CGF was included in diets for lactating dairy cows as a substitute for corn grain and soybean meal (Staples et al., 1984; Armentano and Dentine, 1988), a portion of the forage (Allen and Grant, 2000), or all of the grain mixture and a portion of the forage (Boddugari et al., 2001). Our intent in this experiment was to evaluate the response of lactating cows to DCGF and Chinese wild rye hay in place of a portion of alfalfa hay in diets similar in chemical composition and with sufficient effective fiber. Cows in this study responded by increasing DMI and ECM. Firkins et al. (1991) reported a linear increase in DMI and milk yield when DCGF was substituted for a portion of dietary forage. The DMI response might be attributed to specific gravity and the small particle size of DCGF (Kaske and Engelhardt, 1990). Feedstuffs that have a small particle size might also have a low fill effect (Seoane et al., 1981) and a high transit rate (Giger-Reverdin, 2000). The NDF in CGF was highly degradable (Firkins et al., 1991; VanBaale et al., 2001). Therefore, the total diet DM and NDF digestibility was increased as the amount of DCGF increased in the diets in the current experiment, which was in agreement with Montgomery et al. (2004). The NDF concentrations in the treatment diets of Staples et al. (1984) were 39.2, 42.4 , and $45.2 \%$ of the diet DM when amounts equal to 20,30 , and $40 \%$ WCGF were added, which linearly depressed the DMI and diet DM digestibility as the WCGF increased. The increase in dietary NDF and moisture might explain the depression in DMI. In the present research, the NDF level of 11DCGF was 34.4 $\mathrm{g} / \mathrm{kg}$ of DM, thus the observed increase in DMI may be partially due to a reduction in rumen fill when DCGF replaced a portion of alfalfa in the diets. In addition, other unidentified factors may have stimulated the increase in DMI when animals consumed 11DCGF.

Milk protein, fat, and TS percentage were unaffected by diet when DCGF was fed to lactating cows, which was in agreement with VanBaale et al. (2001) and Gehman and Kononoff (2010). The lactose percentage and yield were also not affected by dietary DCGF, which differs from the report of VanBaale et al. (2001). Milk protein secretion in dairy cows is closely related to the dietary supply of $\mathrm{CP}$, rumen fermentable carbohydrates, and MP (Zhu et al., 2013; Wang et al., 2014), whereas energy supply also plays an extremely important role in MCP synthesis and MP supply for ruminants. Our results indicate that the estimated MCP yield was higher in the cows fed 11DCGF, contributing to a higher milk protein yield. An increase in milk protein percent diets supplemented with a certain proportion of DCGF rather than alfalfa silage or alfalfa hay has also been reported (Allen and Grant, 2000). Cows fed the 11DCGF diet consumed more feed that was more digestible, resulting in a higher energy intake than other treatments, which might promote MCP syntheses. A major benefit of using CGF in ruminant diets is the availability of fermentable fiber as an energy source. Additionally, the higher MCP synthesis in the 11DCGF diet could be attributed to an increased supply of RDP compared with the 0DCGF diet. As reported by Gehman and Kononoff (2010), in rations containing CGF and an increasing NDF content, NDF digestibility played a more important role in determining DM digestibility than in rations with lower concentrations of NDF. The increased NDF and DM digestibility observed for 11DCGF is likely attributable to replacing NDF from alfalfa hay with NDF from DCGF. The long fiber in Chinese wild rye hay also ensured enough time for diets to be digested in the rumen. Increasing NDF digestibility may have in part led to an increase in DMI for 11DCGF. Sarwar et al. (1991) reported that when 20 and $40 \%$ of forage NDF was replaced by CGF, the NDF digestibility was increased significantly.

Compared with the 0DCGF diet, the 11DCGF diet had higher DM degradation (Table 6), resulting from higher $a$ and $c$ values (though a lower $b$ ). Higher $a$ and $c$ values were largely attributable to the higher degradation of WCGF (Montgomery et al., 2004). Those authors concluded that WCGF increased the 
$\mathrm{DMI}$ and total-tract digestibility of $\mathrm{OM}$ and NDF. Allen and Grant (2000) reported that the inclusion of chopped alfalfa hay to a diet containing CGF had higher ruminal mat consistency, resulting in greater ruminal digestion of NDF. The protein of CGF is rapidly degraded in the rumen, which increased the rumen $\mathrm{NH}_{3}$ concentration (Montgomery et al., 2004) and was consistent with the results of Sarwar et al. (1991). Sufficient energy substrate may have been available for bacteria to use ammonia- $\mathrm{N}$ for cows fed the 11DCGF diet, with higher VFA content in the rumen when the 11DCGF diet was provided. All acetate-to-propionate ratios were much greater than 2.5 , the value considered to be the threshold below which milk fat depression occurs (Woodford and Murphy, 1988). Although the concentration of VFA increased because of the increase of alkaline ammonia ions, the ruminal $\mathrm{pH}$ was unaffected. Several trials indicated that the ruminal $\mathrm{pH}$ was either not changed or increased with the addition of CGF (Krehbiel et al., 1995; Montgomery et al., 2004). In the current study, the increased ratio of DCGF in the ration resulted in greater production of acetate, propionate, and butyrate, but no such difference was observed for the acetate to propionate ratios. A previous study (Biricik et al., 2007) detected the same increase in total VFA, propionate, and butyrate, when 10,18 , and $25 \%$ of the corn silage was replaced by DCGF. However, a significant decrease in acetate was observed in that study. Higher total concentrations of ruminal VFA in 7DCGF- and 11DCGF-fed cows were indicative of the higher nutrient digestibility of these 2 diets compared with the ODCGF diet, suggesting increased energy supply to support microbial growth and milk production from the DCGF diet. The concentrate ingredients were similar among the 3 diets; thus, the differences were attributed to the fiber source. Clark et al. (1992) concluded that the ruminal degradation of $\mathrm{DM}$ and $\mathrm{OM}$ is the predominant factor contributing to MCP yield. Therefore, greater ruminal nutrient supply may have stimulated rumen microbial growth and ultimately allowed MCP synthesis to increase.

According to the NRC (2001), urea nitrogen in the blood, urine, and milk in dairy cows is mainly associated with excessive ammonia absorbed through the rumen wall from the degradation of dietary $\mathrm{CP}$ in the rumen and also from the deamination of AA, which may be from MP or body tissue protein. Excessive ammonia in the blood converts to urea in the liver, and the urea is excreted in the rumen, urine, and milk (Linn and Olson, 1995). In the present study, dietary treatments had no effects on urea nitrogen concentration in the blood and milk, and the 0DCGF diet decreased the urea nitrogen concentration in the urine compared with the 11DCGF diet. A higher urea $\mathrm{N}$ concentra- tion in the urine was largely attributable to the higher degradable CP in the 11DCGF diet. The decrease in the urea nitrogen concentration may indicate that the ODCGF diet might have a more balanced AA profile in the MP, resulting in less deamination of the absorbed AA. Additional work is needed to estimate AA utilization efficiency and improve the AA balance when the diets have CGF ingredients.

\section{CONCLUSIONS}

A ration containing 11\% DCGF resulted in greater DMI than a ration without DCGF. Compared with a ration with no DCGF, DM and NDF digestibility was increased for the ration including $6.5 \%$ and $11 \%$ DCGF. Excretion of PD increased when cows were fed a ration containing $11 \%$ DCGF, suggesting that feeding this ration may increase MCP flow to the small intestine. Milk production was not increased when cows were fed ration containing DCGF, suggesting that other nutrient elements such as vitamins, minerals, and AA, might affect milk production. Thus, it appears that feeding DCGF and Chinese wild rye grass in combination can effectively replace a portion of alfalfa hay in rations for lactating dairy cows.

\section{ACKNOWLEDGMENTS}

This research was supported by grants from the China Agricultural Research System (Beijing, China; No. CARS-37). The authors thank the personnel of the Comprehensive Breeding Farm (Harbin, China) for their assistance in the feeding and care of the animals.

\section{REFERENCES}

Allen, D. M., and R. Grant. 2000. Interactions between forage and wet corn gluten feed as sources of fiber in diets for lactating dairy cows. J. Dairy Sci. 83:322-331.

AOAC International. 2000. Official Methods of Analysis. Vol. 1 and 2. 17th ed. AOAC International, Gaithersburg, MD.

Armentano, L. E., and M. R. Dentine. 1988. Wet corn gluten feed as a supplement for lactating dairy cattle and growing heifers. J. Dairy Sci. 71:990-995.

Biricik, H., H. Gencoglu, B. Bozan, B. H. Gulmez, and I. I. Turkmen. 2007. The effect of dry corn gluten feed on chewing activities and rumen parameters in lactating dairy cows. Ital. J. Anim. Sci. 6:61-70.

Boddugari, K., R. J. Grant, R. Stock, and M. Lewis. 2001. Maximal replacement of forage and concentrate with a new wet corn milling product for lactating dairy cows. J. Dairy Sci. 84:873-884.

Boston, R. C., D. G. Fox, C. J. Sniffen, R. Janczewski, R. Munson, and W. Chalupa. 2000. The conversion of a scientific model describing dairy cow nutrition and production to an industry tool: the CPM Dairy project. Pages 361-377 in Modelling Nutrient Utilization in Farm Animals. J. P. McNamara, J. France, and D. Beever, ed. CABI Publishing, Oxford, UK.

Bothast, R. J., and M. A. Schlicher. 2005. Biotechnological processes for conversion of corn into ethanol. Appl. Microbiol. Biotechnol. 67:19-25. 
Broderick, G. A. 2003. Effects of varying dietary protein and energy levels on the production of lactating dairy cows. J. Dairy Sci. 86:1370-1381.

Calsamiglia, S., P. W. Cardozo, A. Ferret, and A. Bach. 2008. Changes in rumen microbial fermentation are due to a combined effect of type of diet and pH. J. Anim. Sci. 86:702-711.

Chen, X. B., and M. J. Gomes. 1992. Estimation of microbial protein supply to sheep and cattle based on urinary excretion of purine derivatives - An overview of the technical details. Rowett Research Institute, Bucksburn, Aberdeen, UK.

Clark, J. H., T. H. Klusmeyer, and M. R. Cameron. 1992. Microbial protein synthesis and flows of nitrogen fractions to the duodenum of dairy cows. J. Dairy Sci. 75:2304-2323.

Farran, T. B., G. E. Erickson, T. J. Klopfenstein, C. N. Macken, and R. U. Lindquist. 2006. Wet corn gluten feed and alfalfa hay levels in dry-rolled corn finishing diets: Effects on finishing performance and feedlot nitrogen mass balance. J. Anim. Sci. 84:1205-1214

Firkins, J. L., M. L. Eastridge, and D. L. Palmquist. 1991. Replacement of corn silage with corn gluten feed and sodium bicarbonate for lactating dairy cows. J. Dairy Sci. 74:1944-1952.

Gargallo, S., S. Calsamiglia, and A. Ferret. 2006. Technical note: A modified three-step in vitro procedure to determine intestinal digestion of proteins. J. Anim. Sci. 84:2163-2167.

Gehman, A. M., and P. J. Kononoff. 2010. Nitrogen utilization, nutrient digestibility, and excretion of purine derivatives in dairy cattle consuming rations containing corn milling co-products. J. Dairy Sci. 93:3641-3651.

Giger-Reverdin, S. 2000. Characterisation of feedstuffs for ruminants using some physical parameters. Anim. Feed Sci. Technol. 86:5369.

Groff, E. B., and Z. Wu. 2005. Milk production and nitrogen excretion of dairy cows fed different amounts of protein and varying proportions of alfalfa and corn silage. J. Dairy Sci. 88:3619-3632.

Heinrichs, A. J., and P. J. Kononoff. 2002. Evaluating particle size of forages and TMRs using the new Penn State Forage Particle Separator. Tech. Bull. DAS:02-42. College Agric. Sci., Cooperative Ext., Pennsylvania State Univ., University Park.

Hristov, A. N., S. Ahvenjarvi, P. Huhtanen, and T. A. McAllister. 2003. Composition and digestive tract retention time of ruminal particles with functional specific gravity greater or less than 1.02 . J. Anim. Sci. 81:2639-2648.

Kaske, M., and W. V. Engelhardt. 1990. The effect of size and density on mean retention time of particles in the gastrointestinal tract of sheep. Br. J. Nutr. 63:457-465.

Kelzer, J. M., P. J. Kononoff, A. M. Gehman, K. Karges, and M. L. Gibson. 2009. Effects of feeding three types of corn milling coproducts on ruminal fermentation and digestibility in lactating Holstein dairy cattle. J. Dairy Sci. 92:5120-5132.

Krehbiel, C. R., R. A. Stock, D. W. Herold, D. H. Shain, G. A. Ham, and J. E. Carulla. 1995. Feeding wet corn gluten feed to reduce subacute acidosis in cattle. J. Anim. Sci. 73:2931-2939.

Krizsan, S. J., S. Ahvenjärvi, and P. Huhtanen. 2010. A meta-analysis of passage rate estimated by rumen evacuation with cattle and evaluation of passage rate prediction models. J. Dairy Sci. 93:5890-5901.

Lee, C., and A. N. Hristov. 2013. Short communication: Evaluation of acid-insoluble ash and indigestible neutral detergent fiber as total-tract digestibility markers in dairy cows fed corn silage-based diets. J. Dairy Sci. 96:5295-5299.

Leonardi, C., M. Stevenson, and L. E. Armentano. 2003. Effect of two levels of crude protein and methionine supplementation on performance of dairy cows. J. Dairy Sci. 86:4033-4042.

Linn, J. G., and J. D. Olson. 1995. Using milk urea nitrogen to evaluate diets and reproductive performance of dairy cattle. Pages 155-167 in 4-State Appl. Nutr. Manag. Conf., La Crosse, WI. University of Wisconsin, Madison.

Mertens, D. R. 1997. Creating a system for meeting the fiber requirements of dairy cows. J. Dairy Sci. 80:1463-1481.

MOA (Ministry of Agriculture of P. R. China). 2004. Feeding Standard of Dairy Cattle (NY/T 34-2004). MOA, Beijing, China.
Montgomery, S. P., J. S. Drouillard, E. C. Titgemeyer, J. J. Sindt, T. B. Farran, J. N. Pike, C. M. Coetzer, A. M. Trater, and J. J. Higgins. 2004. Effects of wet corn gluten feed and intake level on diet digestibility and ruminal passage rate in steers. J. Anim. Sci. $82: 3526-3536$

NRC. 2001. Nutrient Requirements of Dairy Cattle. 7th rev. ed. National Academy Press, Washington, DC.

Nuez-Ortín, W. G., and, and P. Yu.. 2010. Estimation of ruminal and intestinal digestion profiles, hourly effective degradation ratio and potential $\mathrm{N}$ to energy synchronization of co-products from bioethanol processing. J. Sci. Food Agric. 90:2058-2067.

Ørskov, E. R., F. D. De, B. Hovell, and F. Mould. 1980. The use of the nylon bag technique for the evaluation of feedstuffs. Trop. Anim. Prod. 5:195-213.

Orth, R. 1992. Sample day and lactation report, DHIA 200. Fact Sheet A-2. Mid-States Dairy Records Processing Center (DRPC), Ames, IA.

Pereira, M. N., E. F. Garrett, G. R. Oetzel, and L. E. Armentanto. 1999. Partial replacement of forage with nonforage fiber sources in lactating cow diets. I. Performance and health. J. Dairy Sci. $82: 2716-2730$

Rahmatullah, M., and T. R. Boyde. 1980. Improvements in the determination of urea using diacetyl monoxime; methods with and without deproteinisation. Clin. Chim. Acta 107:3-9.

Sarwar, M., J. L. Firkins, and M. L. Eastridge. 1991. Effect of replacing neutral detergent fiber of forage with soyhulls and corn gluten feed for dairy heifers. J. Dairy Sci. 74:1006-1017.

Seoane, J. R., M. Cote, P. Gervais, and J. P. Laforest. 1981. Prediction of the nutritive value of alfalfa (Saranac), bromegrass (Saratoga) and timothy (Champ, Climax, Bounty) fed as hay to growing sheep. Can. J. Anim. Sci. 61:403-413.

Shingfield, K. J., and N. W. Offer. 1999. Simultaneous determination of purine metabolites, creatinine and pseudouridine in ruminant urine by reversed-phase high-performance liquid chromatography. J. Chromatogr. B Biomed. Sci. Appl. 723:81-94.

Staples, C. R., C. L. Davis, G. C. McCoy, and J. H. Clark. 1984. Feeding value of wet corn gluten feed for lactating dairy cows. J. Dairy Sci. 67:1214-1220.

Valadares, R. F. D., G. A. Broderick, S. C. Valadares Filho, and M. K. Clayton. 1999. Effect of replacing alfalfa silage with high moisture corn on ruminal protein synthesis estimated from excretion of total purine derivatives. J. Dairy Sci. 82:2686-2696.

Van Soest, P. J., J. B. Robertson, and A. B. Lewis. 1991. Methods for dietary fiber, neutral detergent fiber, and nonstarch polysaccharides in relation to animal nutrition. J. Dairy Sci. 74:3583-3597.

VanBaale, M. J., J. E. Shirley, E. C. Titgemeyer, A. F. Park, M. J. Meyer, R. U. Lindquist, and R. T. Ethington. 2001. Evaluation of wet corn gluten feed in diets for lactating dairy cows. J. Dairy Sci. 84:2478-2485.

Viands, D. R., P. Sun, and D. K. Barnes. 1988. Pollination control: Mechanical and sterility. Pages 931-960 in Alfalfa and Alfalfa Improvement (Agronomy). A. A. Hanson, D. K. Barnes, and R. R. Hill Jr., ed. Am. Soc. Agron., Crop Sci. Soc. Am., Soil Sci. Soc. Am., Madison, WI.

Wang, B., S. Y. Mao, H. J. Yang, Y. M. Wu, J. K. Wang, S. L. Li, Z. M. Shen, and J. X. Liu. 2014. Effects of alfalfa and cereal straw as a forage source on nutrient digestibility and lactation performance in lactating dairy cows. J. Dairy Sci. 97:7706-7715.

Wang, C., J. X. Liu, Z. P. Yuan, Y. M. Wu, S. W. Zhai, and H. W. Ye. 2007. Effect of level of metabolizable protein on milk production and nitrogen utilization in lactating dairy cows. J. Dairy Sci. 90:2960-2965.

Woodford, S. T., and M. R. Murphy. 1988. Effect of forage physical form on chewing activity, dry matter intake, and rumen function of dairy cows in early lactation. J. Dairy Sci. 71:674-686.

Zhu, W., Y. Fu, B. Wang, C. Wang, J. A. Ye, Y. M. Wu, and J.-X. Liu. 2013. Effects of dietary forage sources on rumen microbial protein synthesis and milk performance in early lactating dairy cows. J. Dairy Sci. 96:1727-1734 